\title{
AVOIDING DOUBLE TAXATION THROUGH THE ASSESSMENT OF INTERNATIONAL TAX TRETIES. CASE: ESP's versus ANAF BRAȘOV
}

Florin Dumiter *

“Vasile Goldiș” Western University of Arad, Romania, e-mail: fdumiter@yahoo.com

\section{Ștefania Amalia Jimon}

"Vasile Goldiș” Western University of Arad, Romania, e-mail: jimonstefania@yahoo.com

\section{Florin Gheorghe Bene}

E-mail: beneflorin74@gmail.com

(Received: January 2019; Accepted: April 2019; Published: June 2019)

\begin{abstract}
International double taxation represents one of the main problems' for which taxpayers have to deal within a world fulfilled with globalization, uncertainty, risk, asymmetrical information and moral hazard. In this sense, in this article it is provided a qualitative overview regarding the appearance and evolution of the main double taxation conventions and their legal framework. In this article it is tackled some important issues, namely: the rationale behind the construction and engaging in double taxation conventions; the need for a coherent and just application of those conventions; the historical appearance and evolution of the double taxation conventions, as well as the quid pro quo OECD Model Convention and UN Model Convention. The conclusions of this article highlight the importance and ultimately need for construction of best practices new and complex multilateral tax convention at the UE level in order to diminish the contagious effects of the treaty shopping practices. The case study presented in this article from the Romanian jurisprudence highlights the multi-faced concept of double taxation and the comprehension approach which must be undertaken in order to solve the complex issues of the international taxation via double taxation treaties.
\end{abstract}

Keywords: OECD and UN Model Conventions, taxation criteria, methods for avoiding international double taxation, judicial double taxation, economical double taxation, bilateral and multilateral agreements, tax behavior, international arbitrage.

\footnotetext{
${ }^{*}$ Corresponding author: Florin Dumiter. E-mail:fdumiter@yahoo.com
} 
Dumiter, F., Jimon, Ș.A., Bene, F.G., (2019)

Avoiding double taxation through the assessment of international tax treties. Case: ESP's versus ANAF Brașov

\section{Introduction}

International tax policy can be regarded as the framework which establishes the legal stipulations concerning different states and which covers the taxation aspects of international transactions. Therefore, the international tax policy focuses on the direct taxation (example: income taxation, real estate taxation, inheritance taxation, assets taxation and social insurances contributions) and also on the indirect taxation (example: added value of assets and services taxation, trading taxation, custom taxation).

International taxation policy can be regarded, also, as a subset of notions, lato senso, of international law. This perspective is, especially, relevant in the context of taxation treaties. However, it is not established, a priori, an international tax legislation applied worldwide to the states which decided to comply with this. Regarding this, the expression "international tax policy" is an improper phrase: this should be formed in essence from the international tax legislation of a certain state (including here the international tax treaties) at the moment it reveals' at "international tax policy" and at "international tax law". These laws can be imposed by a state at federal, national, state or local level. Frequently, the taxation burden manifested by international transactions is imposed on national level.

However, we can note a significant exception of this notion: the European Union imposes directives on the 28 different member states which are governing, inter alia, the manner in which some transactions manifested between the taxation subjects of one of the member states and the taxation subject of another member state must be approached regarding the considerations of taxation. For instance, the VI Directive [1] establishes the rules on the added value taxation of cross-border transactions between member states. On a similar note, the Directive of "Branches" and the Directive regarding "savings" [2] specify precise rules referring the taxation (or non-taxation) of cross-border transactions income (of those types of incomes to which are address the three directives mentioned before) between member states.

The convention generally accepted under the aspects of international tax law establishes that, meanwhile a state is free to set up any tax it wants, it is found in the situation in which it cannot impose tax liabilities on the territory of another state. In other words, the tax jurisdiction cannot be extended to taxation of the taxable objects which are founded in another state. For instance, France cannot perceive taxes of the German citizens based on theirs incomes obtained in Germany. Therefore, commonly the national tax legislation of a state is limited at the taxation subjects and objects which have a connection with that state. These tax laws usually outline two types of activities: (i) the activities of a person resident of one state in foreign states; (ii) the activities of a non-resident in that state.

2 Journal of Legal Studies Volume 23 Issue 37/2019

$S$ sciendo ISSN 2457-9017; Online ISSN 2392-7054.

Web: publicatii.uvvg.ro/index.php/jls. Pages $1-15$ 
Dumiter, F., Jimon, Ș.A., Bene, F.G., (2019)

Avoiding double taxation through the assessment of international tax treties. Case: ESP's versus ANAF Brașov

In this paper we have as objectives the analysis of the evolution of double taxation avoidance conventions. The reason which settled this study was the necessity of consolidation of the legal and economic framework worldwide, lato sensu, and at European level, stricto sensu. The research methodology targeted the historical analysis, the logic method, the deductive method, the inductive method and the case study approach. Moreover, throughout the presentation and analysis of one case from the Romanian jurisprudence we wanted the extrapolation of the problems appeared at national level which forms a quid pro quo to identify the solutions which could solve the problems of double taxation at international level.

This article is structured in the following parts: introduction is the foundation for the presentation of the main objectives of the paper, and also of the aim and reason which stayed at the base of elaboration of the article, as well as the research methodology used. The second part of the paper starts from the presentation of main aspects regarding the double taxation avoidance conventions in the view of different authors at international level, following in the second part of this section to be analyzed in a synthetic manner the evolution of the main double taxation avoidance conventions. The last part of the article represents an analysis of a case from Romanian jurisprudence which highlights the taxation of interest in Romania obtained by non-residents. At the end of the article it can be found the discussions and debates regarding the future evolution of the double taxation avoidance conventions network and summarizes the final considerations of the study.

\section{Literature review}

A double taxation avoidance convention is also known as "double taxation avoidance agreement", "double taxation avoidance treaty" or simple "taxation treaty". "Taxation treaty" is defined in the International Tax Glossary [3] as "a general term used to assign an agreement concluded between two or more states with the purpose of double taxation avoidance".

From the moment of conception of these, the raison d'être of the double taxation treaties was the avoidance of double taxation. The solution of this problem assumed, implicitly, the taxation of incomes just once, which leaded to debates regarding the prerogative of the state which will detain the taxing rights of incomes. Recently, the double taxation avoidance conventions have developed in instruments of prevention of tax avoidance in a cross-border framework [4].

The Committee of Fiscal Affairs of the Organization of Economic Cooperation and Development (OECD) had synthetized the aims of double taxation avoidance conventions: "The main purpose of double taxation avoidance conventions is to promote, by elimination of double taxation, the exchanges of goods and services, and also the free movement of capitals and persons. Another purpose of double taxation avoidance conventions is to prevent avoiding taxes and tax avoidance" [5]. 
Dumiter, F., Jimon, Ș.A., Bene, F.G., (2019)

Avoiding double taxation through the assessment of international tax treties. Case: ESP's versus ANAF Brașov

However, these are not just the mean to accomplish some specific requirements. The allocation dispositions seem to have an aim in itself. These are consolidating the cohesion and the coordination of non-harmonized international taxation, much complained for the distorted effect on trade and investments. From this point of view, the decreasing of double taxation effect is, after all, incidental or corollary to allocation. At the core, the manner in which the OECD Model Convention is structured seems that the ability of decreasing the double taxation depends on the fair allocation of jurisdiction.

The measure in which the international double taxation conventions remove or decrease the double taxation and the discrimination between foreign and resident persons, these reduce the discouraging measures about the international investments and trade, and also the technological transfer. Therefore, these facilitate the movement of capitals, goods, services and persons, concurring to development of economic and trading relationships between states. There are promoting a better allocation and usage of economic resources and investments, at national level and also internationally, and so on to accomplish the allocative efficiency [6]. After all, at the beginning the bilateral treaties were "thought" as a preface of multilateral tax treaties. This waited evolution was not materialized in the expected way, with small exceptions [7].

\section{Evolution of international double taxation avoidance conventions}

Generally, tax treaties were built to encourage the trade between people and ideas. These are supporting the governments to "cement" the tax relationships and to formalize the trade policies vis - á - vis the nations which detain important trade operations or developed states. Concluding a tax treaty is a sign of honor, of legitimacy found on an ascendant stage and an international economic recognition. It is not a surprise that the most traditional tax heaves slightly have tax treaties concluded with nations which hold the power regarding the international trade relationships.

The governments choose better, ipso facto, tax treaties than unilateral solutions. This fact is not due to the reciprocity of tax concessions given, but also because the administrative stipulations of tax treaties which facilitate the tax collecting and tax legislation enforcement. Exchange of information, assistance in tax collecting, establishing some mechanisms to solve potential conflicts, are standard stipulations of tax treaties. After all, it can be advocate that requirement of tax treaties is not given by the possibility of double taxation avoidance, which can be efficiently solved with unilateral measures, but by these administrative stipulation. Moreover, the inter-governmental tax assistance given by tax treaties helps to combat tax fraud and other cross-border irregularities. 
Dumiter, F., Jimon, Ș.A., Bene, F.G., (2019)

Avoiding double taxation through the assessment of international tax treties. Case: ESP's versus ANAF Brașov

Removing tax avoidance, both in the form of announcement effect and also in the form of income effect, has become an important objective of tax treaties, objective quickly targeted by US tax authorities and prevailing in OECD "circles". It can be argued that in Commentary on Art. 1 of OECD Model Convention regarding the improper use of tax treaties, it is stipulated that these cannot help to combating tax avoidance. However, the concepts of tax avoidance and improper use of tax treaties are barely explained in these, generating large confusions about the precise parameters of these objectives. The problems become even more complicated in the case in which the problem of double non-taxation comes into the "equation". There is an actual debate if one of the objectives of tax treaties is to remove the double non-taxation. The Congress of International Tax Association from 2004 held in Austria does not clearly established if one of the objectives of tax treaties is to prevent the double non-taxation. After all, national rapporteurs demonstrated the fact that in certain cases, double non-taxation was not allowed, but even wanted to be applied by negotiators (for example the treaties containing stipulation regarding the tax exemptions).

Probably, the most suggestive example in juridical and economic practice of one double taxation avoidance multilateral convention is represented by the Convention between Nordic Countries from 2996 which is an agreement between Denmark, the Faroe Islands, Finland, Iceland, Norway and Sweden. This multilateral convention is based, lato sensu, on the stipulations of OECD model. Due to the economic importance of extractive natural resources of the region, the Nordic Convention contains specific stipulations regarding the preservation of permanent establishment in the contracting state, and also an "unique" article which are governing the activities related with supervision, exploration and exploitation of hydrocarbon deposits (according with article 21).

Overall, we can argue the fact that the objectives of taxation treaties consist in jurisdiction allocation, removing double taxation, preventing tax evasion and administrative assistance. However, the hierarchy of these objectives is often a topic of debate and a controversy. Moreover, the list is not unchangeable. The new objectives (or new sub-sets of these objectives) can be added, even if these can be accomplish in a large time period to the moment in which there are recognized in an equal mode by the majority states. The flexible nature of OECD Model Convention does not prohibit this fact. However, the OECD Model Convention does not quickly provide support for a new set of objectives or other tax policies made in this purpose. The process is a step-by-step approach and not always transparent, being often interconnected with political pressures coming from the nations with a worldwide significant impact. The policies anti-treaty shopping are an example very suggestive in this case. 
Dumiter, F., Jimon, Ș.A., Bene, F.G., (2019)

Avoiding double taxation through the assessment of international tax treties. Case: ESP's versus ANAF Braşov

4. The case: ESP Ploiesti versus ANAF Brasov regarding the interest taxation of non - residents in Romania

In this section it is presented and analyzed a decision of the High Court of Cassation and Justice of Romania - Administrative and Fiscal Contentious Section, respectively the Decision no. 2881 from September 25, 2015 regarding the solution of the appeal made by defendant Directorate General of Public Finance Brasov against the civil sentence no. 3690 from November 22, 2013 of Bucharest Court of Appeal - VIII Administrative and Fiscal Contentious Section [8].

The contestation made by Directorate General of Public Finance Brasov is regarding the taxation of incomes obtained in Romania by nonresident persons and related late payments penalties.

Further we will analyze the decision of High Court of Cassation and Justice of Romania - Administrative and Fiscal Contentious Section regarding both national tax provisions and the stipulations of the Convention between Romania and Belgium regarding the double taxation avoidance, ratified by Law no.126/16.10.1996, and also the Community regulations regarding the free movement of capital in cases of legal entities which obtain interest incomes in member states.

Circumstances of the case

In July 23, 2012, the claimant ESP - Ploiesti S.R.L. demanded to Bucharest Court of Appeal - VIII Administrative and Fiscal Contentious Section the cancellation of taxing decision no. F - BV 1083/23.12.2011, fiscal inspection report no. F - BV 903/23.12.2011 and decision of solution of administrative complaints no. 314/09.07.2012 and no. 363/31.07.2012 released by the defendant Directorate General of Public Finance Brasov regarding the supplementary tax liabilities consisting in tax on incomes obtained in Romania by legal entities between 01.07.2007 - 31.12.2010 and related late payments penalties.

In the motivation of the case, the claimant ESP - Ploiesti S.R.L. shows that Directorate General of Public Finance Brasov - Tax inspection activity made a partial tax inspection which targeted the corporate tax owed by Romanian legal entities and the tax of incomes obtained in Romania by nonresidents. Following this inspection, the defendant made the fiscal inspection report no. F - BV 903/23.12.2011 and provided the taxing decision no. F - BV 1083/23.12.2011, administrative - fiscal documents contested by the claimant in the present action on the ground of the lack of legal basis.

\section{Solution of first instance}

Throughout the sentence no. 3690 from November 22, 2013 the Bucharest Court of Appeal - VIII Administrative and Fiscal Contentious Section have accepted in part

Journal of Legal Studies Volume 23 Issue 37/2019
ISSN 2457-9017; Online ISSN 2392-7054.
Web: publicatii.uvvg.ro/index.php/jls. Pages 1 - 15


Dumiter, F., Jimon, Ș.A., Bene, F.G., (2019)

Avoiding double taxation through the assessment of international tax treties. Case: ESP's versus ANAF Brașov

the demand made by the claimant ESP - Ploiesti S.R.L. against the defendant Directorate General of Public Finance of Brasov County and cancelled in part the Decision no. 363/31.07.2012, Decision no. 914/09.07.2012, taxing decision no. F BV 1083/23.12.2011, taxing decision no. F - BV 1083/06.04.2012 and the fiscal inspection report no. F - BV 903/23.12.2011, exempting the claimant of the supplementary tax liabilities consisting in tax on incomes obtained in Romania by legal entities and accessories related.

To justify this decision, the first instance recorded the fact that tax authorities are referring to the provisions of Tax Code which are establishing the taxation of incomes obtained in Romania by nonresidents. The instance finds that the articles mentioned into the fiscal inspection report do not refer to "capitalized interests" regarding some loans between private legal entities.

The instance also finds the fact that nonresident persons have the obligation to pay taxes on the taxable incomes obtained in Romania, including the interests obtained from a resident.

According to the Convention between Romania and Belgium regarding the double taxation avoidance the incomes payable by the claimant as interests to the nonresident person, following the concluding of several loan contracts, are taxable in Romania.

The tax authorities have omitted the chargeability of the tax obligation, which according with the regulations in force is owed at the payment of the tax. In this case, according with the expertise report, the claimant does not made a crossborder payment with the title of interests to a nonresident lender. Since the payment of these interests was not made, the tax payment obligation regarding these incomes does not exist.

Tax obligation of nonresident and the right to a tax claim regarding the interest incomes is born, not at the moment of establishing the tax base which generates it (the interest being due, according with the contracts of the parties, monthly), but at the moment of the payment to the nonresident. Related with the payment, it is born the obligation of the claimant to compute, retain at source and pay the tax.

Even if the nonresident persons owe the tax on incomes obtained, these are computed, retained and payed at the moment of the payment of the interest to the nonresident. Following that the obligation to pay this tax by the claimant is not chargeable, and the disputed administrative documents are not in accordance with the actual situation because the tax is not due as long as the income was not payed. Another reason of illegality of the administrative - fiscal documents contested is the ignorance by the fiscal authorities of the provisions of the Convention of the Romanian Government and the Belgium Government to double taxation avoidance and prevention of tax evasion regarding the income and capital taxation. This imposes the taxation of interest incomes in the residence state of the lender. In this 
Dumiter, F., Jimon, Ș.A., Bene, F.G., (2019)

Avoiding double taxation through the assessment of international tax treties. Case: ESP's versus ANAF Brașov

case, the interests coming from Romania, and payed by the claimant ESP Sighisoara S.R.L. to the lender SA. CDR S.A., Belgium resident, are taxable in Belgium.

The fundamental law gives priority to international regulation, respectively to Law no. 126/1996 regarding the ratification of the Convention of the Romanian Government and the Belgium Government to double taxation avoidance and prevention of tax evasion regarding the income and capital taxation signed at Brussels in 4th March 1996.

The methodological norms of applying the provisions of Tax Code refer to international double taxation avoidance conventions and specify the fact that the nonresident persons can benefit from the provisions of conventions only if they prove the residence in the partner state by presenting the tax residence certificate. The claimant ESP - Ploiesti S.R.L. presented the tax residence certificate of their lender.

Based on all presented information, the Bucharest Court of Appeal - VIII Administrative and Fiscal Contentious Section noted that the establishment of additional tax obligations by Romanian tax authorities to the claimant is illegal.

\section{The appeal}

Against the decision of Bucharest Court of Appeal - VIII Administrative and Fiscal Contentious Section the appellant-defendant Directorate General of Public Finance Brasov has appealed.

To motivate the appeal demand, the defendant claimed that the first instance does not manifested an active role and has taken the claimant arguments without analyzing the tax authority defenses which demonstrated the legally of the contested documents and debts, and the sentence does not include the factual and legal grounds that led to the wrong conviction of the court.

The appellant-defendant also claims that the solution is illegal, based on the wrong interpretation of the legal provision and successive juridical acts occurred between the parties of loan contract because the transformation of the interests owed into a new loan beginning with 1st May 2008 represents a form to close the debt to CDR S.A. from Belgium, consisting in interest incomes related to non-reimbursable loans. Therefore, the income obtained from interests by the nonresident person in Romania is taxable, regardless the manner in which the lender received the fruit of his capital.

Also, based on international double taxation avoidance convention, the incomes obtained by CDR are taxable with a rate of $10 \%$ of interest gross amount, the tax perceived in Romania on the interest income being exempted from the Belgium tax related to these incomes.

8 Journal of Legal Studies Volume 23 Issue 37/2019

S sciendo ISSN 2457-9017; Online ISSN 2392-7054.

Web: publicatii.uvvg.ro/index.php/jls. Pages $1-15$ 
Dumiter, F., Jimon, Ș.A., Bene, F.G., (2019)

Avoiding double taxation through the assessment of international tax treties. Case: ESP's versus ANAF Brașov

The appellant-claimant ESP - Ploiesti S.R.L. had noticed the European Court of Justice to clarify some aspects regarding the discriminatory treatment of nonresident persons in Romania and the taxation of their incomes obtained from Romanian territory.

On this demand, the appellant-defendant showed that the interpretation of national legislation does not fall in the competence of European Court of Justice, and the criticism regarding the discriminatory treatment of nonresident legal entities in Romania is unfounded.

The citation demand made by the appellant-claimant was rejected on the consideration of the lack of competency of European Court of Justice to interpret the international treaties and more over the ones regarding the validity and interpretation of acts adopted by the community institutions. Therefore, the national instance must decide if a provision of national law is or is not incompatible with Community legislation and international law.

The judgments of High Court of Cassation and Justice of Romania Administrative and Fiscal Contentious Section on the appeal in case

Examining the case in the light of the motives invocated in the appeal, the High Court of Cassation and Justice of Romania - Administrative and Fiscal Contentious Section notices that the appeal is unfounded, without identifying reasons to attract the reformation of the decision of first instance.

The appealed instance found that appellant-claimant have initiated an action targeting the debts established by the defendant Directorate General of Public Finance Brasov consisting in tax on incomes obtained in Romania by nonresident legal entities and related accessories.

The High Court notices from the evidence material that the claimant entity, having the quality of debtor, closed with S.C. CDR S.A. from Belgium, in the quality of lender, a term loan contract, authenticated for the amount of 30,000,000 Euros. This contract was subsequently amended by six additional acts, whereby the total amount of the loan was periodically increased by including the capitalized interest generated by the term loan under art. 5 of the contract, as amended by the additional act no. 1/01.05.2008, according to which the interests should be capitalized and their payment will be made at the time of reimbursement of capital, at the end of the project.

Following the inspections made by the tax authorities for the period 01.07.2007 31.12.2010 it has notice that appellant-claimant ESP - Ploiesti S.R.L. recorded in the accountancy gross amounts owed as "interest" in a total amount of $16,955,061.82$ lei to the date of 31st December 2010, as a consequence was computed the income tax obtained by nonresidents by applying a $10 \%$ rate on this amount, according with Tax Code provisions. 
Dumiter, F., Jimon, Ș.A., Bene, F.G., (2019)

Avoiding double taxation through the assessment of international tax treties. Case: ESP's versus ANAF Brassov

The Bucharest Court of Appeal - VIII Administrative and Fiscal Contentious Section has admitted the action based on the Tax Code articles which are establishing that the tax on incomes owed at the time of the payment of income, operation which was not done, since the interest should be payed at the end of the project. Also, the first instance noted that tax authorities does not applied right the legislation in force at the targeted period by tax inspection, because they used the phrase "capitalized interest", and that notion was not provided in the articles invocated as the basis for the taxation. On the other hand, the Convention of the Romanian Government and the Belgium Government to double taxation avoidance and prevention of tax evasion regarding the income and capital taxation, ratified by Law no. 126/1996 foresees the possibility of taxation by source retaining of interest incomes in the contracting state from which the incomes become, in a rate of maximum $10 \%$ from the gross interest amount and the tax perceived on these incomes should be exempted from the taxes owed in the other state, but the general rule is that taxation of incomes obtained from interests to be made in the residence state of the lender, in case Belgium.

Based on these considerations first instance decided to remove the administrative fiscal documents ant to exonerate the claimant for the payment of the disputed tax obligations.

The High Court of Cassation and Justice of Romania - Administrative and Fiscal Contentious Section removes some considerations which have grounded the decision of first instance because it considers that through the capitalization of interest related to the loan contracted and by including their value into the global borrowed amount, it was made a transformation of the interests payment obligation into a new loan, which carries interests, this situation is equivalised with a payment for which is due the nonresident income tax.

Therewith, the consideration of first instance regarding the improper use of phrase "capitalized interests", in the conditions in which this phrase was not provided in the articles invocated as legal basis of taxation, will be removed because the operation of "capitalizing" the interest was provided in additional act no. 1 of the loan contract concluded between the appellant-claimant and nonresident society, the tax authority applying the provisions of Tax Code which are referring to the interests and royalty incomes, at the fact tax status established based on the contracting clauses and the records from accounting books.

Removing these considerations which have founded the conviction of first instance does not attract the acceptance of the appellant-defendant Directorate General of Public Finance Brasov action. The High Court of Cassation and Justice of Romania - Administrative and Fiscal Contentious Section retains that during the settlement of the case, the legislator added a new article in the Tax Code with the purpose to solve the cases of infringement of the right of European Union regarding the free

10 Journal of Legal Studies Volume 23 Issue 37/2019

$S$ sciendo ISSN 2457-9017; Online ISSN 2392-7054.

Web: publicatii.uvvg.ro/index.php/jls. Pages $1-15$ 
Dumiter, F., Jimon, Ș.A., Bene, F.G., (2019)

Avoiding double taxation through the assessment of international tax treties. Case: ESP's versus ANAF Braşov

movement of providing services and capital in case of foreign legal entities which are obtaining interest incomes in Romania. The new regulation provide the possibility that nonresident legal entities which believe they are discriminated by the application of the tax regime provided by double taxation avoidance conventions have the right to opt for the application of a system of declaration and paying the profit tax, according with the rules applied to resident legal entities which obtain interest incomes.

The modification brought to legislation were adopted on the ground of infringement of European Union law and took into account the motivated opinion of the European Commission no. 2009/4343, concerning the discriminatory tax treatment applied to nonresident legal entities which obtain interest income.

Regarding this, it can be noted that the European Commission establishes a new juridical order of international law, in the benefit of which the states has limited their sovereign rights and the subjects of which are both member states and also their nationals.

Independent of member states legislation, the European Union legislation gives rights expressly by the Treaty, but in the virtue of the obligations that the Treaty is imposing in a well-defined manner both on individuals, member states and European institutions. Therefore, according with the jurisprudence of the European Court of Justice (ECJ), the community right can be invocated by the nationals of member states at juridical instances. The decisions of ECJ had defined the essential characteristics of European law, specifically: priority of European laws, the direct effect of European norms against the national instances, the obligation of interpretation of intern law according with community right, the national procedural autonomy in the application of European law and the reparation of the prejudice caused to persons by the infringement of the community rules by the state. In Romania, the fundamental law establishes the priority of application to the European law and of the international rights against the intern legislation provisions.

As a consequence, as the present litigation did not present an irrevocable solution during the establishment of Tax Code modifications, the new regulations are applicable to the present case. Therefore, the appeal instance considers that the first instance solution represents an adequate remedy to remove the effects of applying one national norm contrary to European Union right in the matter of free movement of capital in case of foreign legal entities which obtain interest incomes from Romania.

The solution of the court of appeal and its legal basis

Based on the above presented consideration, the High Court of Cassation and Justice of Romania - Administrative and Fiscal Contentious Section reject the 
Dumiter, F., Jimon, Ș.A., Bene, F.G., (2019)

Avoiding double taxation through the assessment of international tax treties. Case: ESP's versus ANAF Braşov

appeal of Directorate General of Public Finance Brasov against the civil sentence no. 3690 from November 22, 2013 of Bucharest Court of Appeal - VIII Administrative and Fiscal Contentious Section as unfounded.

\section{Conclusions}

Analyzing the judicial literature we can note that every double taxation avoidance convention is distinctly negotiated. However, lots of double taxation avoidance convention in the world are similar each other. This fact can be "drawn" to different model conventions made by international organizations. These double taxation avoidance model conventions usually start from bilateral negotiations. The parties involved into negotiations must negotiate only those parts from the Model Convention, which want to deviate.

Regarding the multilateral cases, we can note that these are unique in their manner, being able to find enough deficiencies, which could lead to the same cases, under similar auspices. We consider that the strongest argument is represented by the failure of double taxation avoidance bilateral conventions to take into account the effect of other bilateral conventions, whether they are an assignment of tax rights established under the distributive rules of conventions, or they are an allocation of residency under the auspices of a special disposal. However, it will not be sufficient to insert certain general principles to make these conventions to interact. In this case, it is essential to be specified the exact manner in which a certain convention should regard the results of another double convention avoidance convention applied.

The analyze of the case from Romanian jurisprudence and its results suggest the fact that it is not an universal valid solution to solve all problems and inefficiencies found on double taxation avoidance convention, and also the vicious application of these in certain situations. Therefore it is recommendable to establish a double taxation avoidance multilateral convention, which can "rectify" the failures recorded by bilateral tax treaties regarding the avoidance of double taxation, and also the fair taxation of incomes and profits obtained by contributors at international level.

Finally, we can sustain the fact that the over 80 tax conventions concluded by Romania should be just the foundation for new financial, tax and juridical means to uniform and fair interpretation of these. The complexity of international double taxation problem will need a better cooperation between the tax authorities from member states regarding the tax field, will require a tax space, multidisciplinary researches and also specialists with expertise and experience in tax field.

\footnotetext{
Journal of Legal Studies Volume 23 Issue 37/2019

$S$ sciendo ISSN 2457-9017; Online ISSN 2392-7054.

Web: publicatii.uvvg.ro/index.php/jls. Pages $1-15$
} 
Dumiter, F., Jimon, Ș.A., Bene, F.G., (2019)

Avoiding double taxation through the assessment of international tax treties. Case: ESP's versus ANAF Brașov

\section{Acknowledgements}

The authors thank the anonymous reviewers and editor for their valuable contribution.

\section{Funding}

This research received no specific grant from any funding agency in the public, commercial, or not - for - profit sectors.

\section{Author Contributions}

FCD conceived the study and were responsible for the design and development of the conceptual framework. S,J was responsible for the judicial case collection and also for case study interpretation and analysis. FGB was responsible for the literature review section and the methodological aspects.

\section{Disclosure Statement}

The authors have not any competing financial, professional, or personal interests from other parties.

\section{References}

1. Bloningen, B.A., Davies, R.B. (2000). The Effects of Bilateral Tax Treaties on US FDI Activity, NBER Working Paper, No. 7929.

2. Bloningen, B.A., Davies, R.B. (2002). Do Bilateral Treaties Promote Foreign direct Investment, NBER Working Paper, No. 8834.

3. European Council Directive EC/112/2006 of 28 November 2006 on the harmonization of Member States' legislation on turnover taxes - a common system for charging the Value Added Tax: establishment of a unitary basis.

4. Council of Europe Directive EEC/435/90 of 23 July 1990 on the common system of taxation applicable in the case of parent companies and subsidiaries of different Member States.

5. Council of Europe Directive EC/48/2003 of 3 June 2003 on the taxation of savings income in the form of interest payments.

6. Hubfauer, G.C. (1975). A Guide to Law and Policy, US Taxation of Mexican Business Abroad, American Enterprise Institute, Hoover Institution.

7. Kosters, B. (2004). The United Nations Model Tax Convention and its Recent Developments, Asia - Pacific Tax Bulletin, 1/2.

8. McIntyre, M.J. (2005). Developing Countries and International Cooperation on Income Tax Matters: An Historical Review, unpublished manuscript, 2005.

9. Musgrave, R.A. (1960). Criteria for Foreign Tax Credit, in Baker et al. (eds), Taxation and Operations Abroad, Symposium Conducted by the Tax Institute, December 3-4, Princeton, Tax Institute. 
Dumiter, F., Jimon, Ș.A., Bene, F.G., (2019)

Avoiding double taxation through the assessment of international tax treties. Case: ESP's versus ANAF Brașov

10. Musgrave, P.B. (1969). US Taxation of Foreign Investment and Income: Issues and Arguments, Cambridge, Mass: Harvard Law School.

11. Panayi, C. (2007). Double Taxation, Tax Treaties, Treaty Shopping and the European Community, Kluwer Law International, EUCOTAX Series on European Taxation.

12. Reimer, E., Rust, A. (2015). Klaus Vogel on Double Taxation Conventions Fourth Edition - Volume I, Wolters Kluwer Law \& Business.

13. Reimer, E., Rust A. (2015). Klaus Vogel on Double Taxation Conventions Fourth Edition - Volume II, Wolters Kluwer Law \& Business.

14. Rogers - Glabush, J. (eds) (2009). International Tax Glossary, Amsterdam: International Bureau of Fiscal Documentation, 6th Edition at http://online.ibdf.org.

15. Thuronyi, V. (2001). International Tax Co-operation and a Multilateral Treaty, 26 Brooklin Journal of International Law.

16. Vogel, K. (1989). World-Wide v. Source Taxation on Income - A Review and Re-evaluation of Arguments, in McLure, Charles et al (eds), Influence of Tax Differentials on International Competitiveness, Proceedings of the VIIthe Munich Symposium on International Taxation, Kluwer Law and Taxation Publishers.

17. Vogel, K. (2002). Which Method Should the European Community Adopt for the Avoidance of Double Taxation?, I.B.D.F 56.

18. Winjen, W.F.G., Magenta, M. (1997). The UN Model in Practice, 51 Bulletin for International Fiscal Documentation 12.

19. *** Law no. 571/2003 regarding the Tax Code, with further up-dates, including its implementing rules.

20. *** O.G. no. 92/2003 regarding the Tax Procedure Code with further up-dates, including its implementing rules.

21. *** Law no. 227/2015 regarding the Tax Code, with further up-dates, including its implementing rules.

22. *** Law no. 207/2015 regarding the Tax Procedure Code with further up-dates, including its implementing rules.

23. *** Law no. 241/2005 to prevent and combat tax evasion, with further up-dates 24. *** Order no. 222/2008 from 8 February 2008 regarding the content of the file on transfer pricing.

25. Order no. 2309/2017 of 1 August 2017 amending the Order of the President of the National Agency for Fiscal Administration no. 3.626 / 2016 establishing the list of reporting jurisdictions with which Romania will cooperate on the basis of the Multilateral Agreement of Competent Authorities for Automatic Exchange of Information on Financial Accounts, the List of Non-Ferrous Financial Institutions and the Excluded Accounts List, provided in the legal instruments of international law to which Romania has engaged in the automatic exchange of financial information, published in: Official Gazette no. 635 of 3 August 2017

14 Journal of Legal Studies Volume 23 Issue 37/2019

$S$ sciendo ISSN 2457-9017; Online ISSN 2392-7054.

Web: publicatii.uvvg.ro/index.php/jls. Pages $1-15$ 


\section{Notes:}

[1] Council Directive 2006/112/EC of 28 November 2006 on the harmonisation of the laws of the Member States relating to turnover taxes - Common system of value added tax: uniform basis of assessment.

[2] Council Directive 2003/48/EC of 3 June 2003 on taxation of savings income in the form of interest payments.

[3] Rogers - Glabush, J. (eds), International Tax Glossary, Amsterdam: International Bureau of Fiscal Documentation, 2009, 6th Edition at http://online.ibdf.org.

[4] Panayi, C., Double Taxation, Tax Treaties, Treaty Shopping and the European Community, Kluwer Law International, EUCOTAX Series on European Taxation, 2007, pp. 15.

[5] Commentary of Organization of Economic Cooperation and Development about Art. 1, Para. 7.

[6] According with Bloningen, B.A. \& Davies, R.B., The Effects of Bilateral Tax Treaties on US FDI Activity, NBER Working Paper No. 7929, 2000, pp.21. They claim that removing double taxation has a significant positive effect on direct foreign investments. Also the article: Bloningen, B.A. \& Davies, R.B., Do Bilateral Treaties Promote Foreign direct Investment, NBER Working Paper No. 8834, 2002, pp. 2,7. In the last mentioned article, the authors highlight that, per ensemble, cannot be empirically demonstrated the fact that double taxation conventions are promoting the direct foreign investments. After all, the authors argue that this convention can decrease the double taxation avoidance and other strategies of taxation avoidance used by societies, having a dumping effect on direct foreign investments. This fact can occur, because the direct foreign investments were, first of all, excessive.

[7] Thuronyi, V., „International Tax Co-operation and a Multilateral Treaty”, 26 Brooklin Journal of International Law, 2001, pp. 1641.

[8] High Court of Cassation and Justice of Romania - Administrative and Fiscal Contentious Section, Decision no. 2811, pronounced in public session from September 25, 2015, Folder no. 5938/2/2012 